\title{
IMPLEMENTASI PEMBELAJARAN INKUIRI TERBIMBING BERBASIS PERMAINAN DALAM MENINGKATKAN KREATIVITAS ANAK USIA DINI
}

\author{
Ni Made Ayu Suryaningsih ${ }^{1}$, I Made Elia Cahaya ${ }^{2}$, Christiani Endah Poerwati ${ }^{3}$
1,2,3 Program Studi Pendidikan Guru-Pendidikan Anak Usia Dini, Universitas Dhyana Pura, Indonesia \\ E-mail : suryaningsih_ayu@ymail.com ${ }^{1}$
}

\begin{abstract}
Abstrak
Penerapan pembelajaran pada anak usia dini saat ini masih cenderung menggunakan metode pembelajaran konvensional seperti ceramah. Hal ini mengakibatkan rendahnya perkembangan kreativitas anak. Sehingga dibutuhkan suatu cara dalam meningkatkan kreativitas anak usia dini. Penelitian ini bertujuan untuk mengetahui pengimplementasian metode pembelajaran inkuiri terbimbing berbasis permainan dalam meningkatkan kreativitas anak usia dini. Jenis penelitian ini adalah Penelitian Tindakan Kelas (PTK) dengan menggunakan metode observasi. Subjek penelitian tindakan kelas ini adalah siswa di TK Pradnyandari III, dengan objek penelitian implementasi model pembelajaran inkuiri terbimbing berbasis permainan terhadap peningkatan kreativitas anak usia dini. Pada observasi awal, ketuntasan kreativitas anak hanya mencapai $22,72 \%$. Pada penerapan metode pembelajaran inkuiri terbimbing berbasis permainan dalam siklus I terjadi peningkatan kreativitas anak menjadi 54,54\%. Dan kembali mengalami peningkatan pada siklus II menjadi $86,36 \%$. Sehingga dapat disimpulkan bahwa implementasi metode pembelajaran inkuiri terbimbing berbasis permainan dapat meningkatkan kreativitas anak usia dini.
\end{abstract}

Kata Kunci : Kreativitas, Inkuiri Terbimbing Berbasis Permainan.

\begin{abstract}
The application of learning in early childhood is now still tend to use conventional methods of learning with teacher centered approach. This has resulted in the low the development creativity children. So it needs a way in creative early childhood. Research aims to understand the implementation of guided inquiry learning based game to increases creativity in early childhood. The kind of research is classroom action research by using observation method. The subject of this study is students in Pradnyandari III Kindergarten, with the object the implementation of guided inquiry learning based game to increases creativity in early childhood. In preliminary observations, completeness creativity only reach $22,72 \%$. Affected the implementation of the implementation of guided inquiry learning based game in cycles 1 been an increase in creativity the son to be $54,54 \%$. And increase again in cycle II be $86,36 \%$ .So that we can conclude that the implementation of guided inquiry learning based game can increase creativity in early childhood
\end{abstract}

Keywords: Creativity, Guided Inquiry Learning Based Game.

\section{PENDAHULUAN}

Pendidikan merupakan hak yang harus diperoleh oleh seluruh masyarakat. Pendidikan memiliki peran yang menentukan bagi perkembangan individu terutama bagi pembangunan bangsa dan
Negara. Dalam program pembangunan nasional, pengembangan pendidikan merupakan salah satu wahana yang sangat penting, karena melalui pendidikan dapat meningkatkan kualitas sumber daya manusia. 
Hal tersebut tidak terkecuali pada tingkatan pendidikan bagi anak usia dini. Berdasarkan data yang diperoleh penulis dari UPT Dinas Pendidikan Pemuda dan Olahraga Kecamatan Kuta Utara tahun 2015, dapat diketahui bahwa tenaga kependidikan yang linier terhadap pendidikan anak usia dini masih minim (hanya 11,86\%). Sehingga dalam penerapan proses pembelajaran cenderung menggunakan model pembelajaran konvensional, dengan metode ceramah dan hanya menggunakan media gambar atau buku yang membuat anak jenuh mengikuti pembelajaran. Metode pembelajaran yang kurang berkesan membuat anak sulit mengembangkan kreativitasnya.

Pelaksanaan pendidikan untuk anak usia dini masih cenderung menggunakan metode pembelajaran konvensional dengan pendekatan Teacher centered. Hal tersebut mengakibatkan selama proses pembelajaran siswa lebih banyak diam dan kurang berani menyampaikan pendapat dan ide-idenya. Ketika pertanyaan diberikan dalam pembelajaran, kemampuan siswa dalam memahami pembelajaran masih rendah. Hal ini terlihat dari jawaban siswa yang satu dengan yang lainnya sebagian besar sama, siswa juga menjadi kurang kreatif dalam menemukan solusi jawaban yang lainnya.

Piaget,dalam (E. Mulyasa, 2007) mengemukakan bahwa inkuiri merupakan pendekatan yang mempersiapkan peserta didik pada situasi untuk melalukan eksperimen diri secara luas agar melihat apa yang terjadi, ingin melakukan sesuatu mengajukan pertanyaan-pertanyaan dan mencari jawabannya sendiri serta menghubungkan penemuan yang satu dengan dengan penemuan yang lain, membandingkan apa yang di kemukakan dengan yang ditemukan peserta didik lain.

Pembelajaran inkuiri merupakan kegiatan pembelajaran yang melibatkan secara maksimal seluruh kemampuan siswa untuk mencari dan menyelidiki sesuatu (benda, manusia atau peristiwa) secara sistematis dalam mengamati gambar, kritis dalam memberikan pertanyaan, analitis sehingga mereka dapat merumuskan sendiri penemuannya dengan penuh percaya diri. Pembelajaran inkuiri menekankan kepada proses mencari dan menemukan. Materi pelajaran tidak diberikan secara langsung. Peran siswa dalam pembelajaran ini adalah mencari dan menemukan sendiri materi pelajaran, sedangkan guru berperan sebagai fasilitator dan pembimbing siswa untuk belajar. Pembelajaran inkuiri merupakan rangkaian kegiatan pembelajaran yang menekankan pada proses berpikir kritis dan analitis untuk mencari dan menemukan sendiri jawaban dari suatu masalah yang dipertanyakan. Permainan simulasi ini dibuat untuk tujuantujuan tertentu misalnya untuk membantu siswa mempelajari pengalamanpengalaman yang berkaitan dengan aturanaturan sosial (Fithriyana, 2014).

Dalam proses belajar mengajar dengan metode inkuiri terbimbing, siswa dituntut untuk menemukan konsep melalui petunjuk-petunjuk seperlunya dari seorang guru. Petunjuk-petunjuk itu pada umumnya berupa pertanyaan-pertanyaan yang bersifat membimbing (Wartono 1999). Selain pertanyaan-pertanyaan, guru juga dapat memberikan penjelasan-penjelasan seperlunya pada saat siswa akan melakukan percobaan, misalnya penjelasan tentang cara-cara melakukan percobaan. Metode inkuiri terbimbing digunakan bagi siswasiswa yang belum berpengalaman belajar dengan menggunakan metode inkuiri. Salah satu alternatif yang tepat untuk membangkitkan motivasi siswa dalam pembelajaran fisika adalah menerapkan suatu metode yang memberikan siswa peluang untuk mengkonstruksi pemahaman konsepnya sendiri dan menumbuh kembangkan kinerja ilmiahnya. Salah satu metode itu adalah dengan metode inkuiri terbimbing. Amri (Sudarma, 2012).

Guru dapat memberikan kemudahan untuk proses ini, dengan memberi kesempatan siswa untuk menemukan atau menerapkan ide-ide sendiri, dan mengajar siswa menjadi sadar dan secara sadar menggunakan strategi mereka sendiri untuk belajar (Wahyudin, 2010). inkuiri terbimbing adalah metode mengajar yang memberikan pengalaman belajar langsung, melibatkan aktivitas, dan mengajak siswauntuk melakukan kegiatan percobaan berupa penemuan yang dapat membantu siswa memahami konsep fisika (Wijayanti, 2010). 
Inkuiri terbimbing Menurut Trianto (dalam Maghfiroh, 2012) menyatakan bahwa inkuiri adalah suatu proses umum yang dilakukan manusia untuk mencari atau memaha-mi informasi. Pembelajaran inkuiri terbimbing meliputi beberapa fase yang harus dilakukan yaitu, fase perumusan masalah, fase membuat hipotesis, fase eksperi-men, fase menguji hipotesis, fase membuat kesimpulan. Keberhasilan penerapan model inkuiri terbimbing (guided inquiry) terhadap keterampilan proses sains siswa (scientific process skills) telah dibuktikan oleh Hatminingsih (dalam Jumarni, 2013) melalui penelitiannya yang menyimpulkan bahwa penggunaan model inkuiri terbimbing dapat meningkatkan keterampilan proses sains siswa SMA pada materi sistem gerak manusia.

Kauchack (dalam Astuti, 2013) menyatakan inkuiri merupakan salah satu cara efektif yang dapat membantu siswa meningkatkan keterampilan berpikir dengan menggunakan proses mental lebih tinggi dan keterampilan berpikir kritis. Menurut Andriani (2015) metode pembelajaran inkuiriterbimbing adalah salah satu metode pembelajaran yang melibatkan partisipasi aktif siswa dalam mengeksplorasi dan menemukan sendiri pengetahuan mereka. $\mathrm{Hal}$ tersebut didukung oleh Hidayatullah, (2011) yang menyatakan salah satu tujuan mengajar dan mendidik adalah menumbuhkan kemampuan berfikir kritis melalui pelaksanaan tugas-tugas pembelajaran.

Menurut Gulo (dalam Ambarsari, 2013) berarti suatu rangkaian kegiatan belajar yang melibatkan secara maksimal seluruh kemampuan siswa untuk mencari dan menyelidiki secara sistematis, kritis, logis, analitis, sehingga mereka dapat merumuskan sendiri penemuannya dengan penuh percaya diri.

Permainan merupakan hal yang sangat dekat dengan dunia anak. Oleh karena itu permainan merupakan rangsangan yang tepat bagi anak-anak. Melalui permainan memungkinkan anakanak mengembangkan kompetensi dan ketrampilann yang diperlukannya dengan cara yang menyenangkan. Bermain adalah salah satu cara untuk melatih anak konsentrasi karena anak mencapai kemampuan maksimal ketika terfokus pada kegiatan bermain dan bereksplorasi dengan mainan. Menurut Christianti (2007) dinyatakan bahwa bermain juga dapat membentuk belajar yang efektif karena dapat memberikan rasa senang sehingga dapat menimbulkan motivasi instrinsik anak untuk belajar. Keberhasilan penerapan model inkuiri terbimbing (guided inquiry) terhadap keterampilan proses sains siswa (scientific process skills) telah dibuktikan oleh Hatminingsih (dalam Jumarni, 2013) melalui penelitiannya yang menyimpulkan bahwa penggunaan model inkuiri terbimbing dapat meningkatkan keterampilan proses sains siswa SMA pada materi sistem gerak manusia.

Berdasarkan karakteristik anak dan dunianya dapat diketahui bahwa permainan tidak dapat dipisahkan dari perkembangan anak serta dalam mengembangkan pemahaman dan kreativitas anak masih membutuhkan bantuan-bantuan dari guru. Berdasarkan latar belakang tersebut, maka permasalahan yang dikaji dalam penelitian ini yakni apakah penerapan model pembelajaran inkuiri terbimbing berbasis permainan dapat meningkatkan kreativitas anak usia dini?

\section{METODE}

Penelitian ini menggunakan design penelitian tindakan kelas (classroom action research) yang secara umum bertujuan untuk meningkatkan kreativitas anak usia dini. Siklus dari PTK ini terdiri dari empat tahapan yaitu perencanaan tindakan, pelaksanaan tindakan, observsi/evaluasi, dan refleksi (Madya, 2011). Penelitian ini dilakukan untuk melihat efektifitas metode pembelajaran inkuiri terbimbing (guided inquiry) berbasis permainan dalam meningkatkan kreativitas anak usia dini, sehingga diharapkan dapat menjadi metode pembelajaran yang dapat diterapkan oleh tenaga pengajar pada pendidikan anak usia dini.

Subjek penelitian tindakan kelas ini adalah siswa TK di TK Pradnyandari III. Sedangkan objek penelitian tindakan kelas yang dilakukan terhadap subjek penelitian di tingkat pendidikan Taman Kanak-kanak adalah sebagai berikut; 1) Penerapan metode pembelajaran inkuiri terbimbing 
(guided inquiry) berbasis permainan dalam proses pembelajaran anak usia dini, dan 2) Peningkatan kreativitas anak usia dini, yaitu kemampuan anak dalam menghasilkan sesuatu yang baru, baik berupa gagasan maupun karya nyata yang relatif berbeda dengan yang pernah ada dan menerapkannya dalam memecahkan masalah dengan metode-metode baru.

Data peningkatan kreativitas anak dianalisis secara deskriptif, yaitu dengan makukan observasi terhadap aktifitas yang dilakukan anak dengan bantuan instrument penilaian. Keberhasilan anak dalam peningkatan kreativitas dikatagorikan menjadi lima katagori yaitu sangat tinggi, tinggi, sedang, rendah dan sangat rendah. Cara menghitungnya adalah dengan mencari rata-rata, minimal memenuhi katagori baik. Tingkat kreativitas anak dapat ditentukan dengan membandingkan persentase penguasaan ke dalam konversi Penilaian Acuan Patokan (PAP) skala lima, yang tertera pada Tabel 1.

Kriteria keberhasilan dalam penelitian ini adalah jika terjadi peningkatan kreativitas anak melalui penerapan pembelajaran inkuiri terbimbing berbasis permaianan. Indikator keberhasilan dalam penelitian ini apabila minimal $80 \%$ dari jumlah anak didik memenuhi kriteria sedang.

Tabel 1. Tabel Pedoman Konversi Penilaian Acuan Patokan (PAP)

\begin{tabular}{ccc}
\hline Persentase Penguasaan & Katagori & Ketuntasan \\
\hline $90-100$ & Sangat tinggi & Tuntas \\
$80-89$ & Tinggi & Tuntas \\
$65-79$ & Sedang & Tuntas \\
$55-64$ & Rendah & Belum Tuntas \\
$00-54$ & Sangat rendah & Belum Tuntas
\end{tabular}

\section{HASIL DAN PEMBAHASAN}

Hasil yang diperoleh dalam penelitian ini meliputi peningkatan kreativitas anak usia dini melalui metode pembelajaran inkuiri terbimbing berbasis permainan. Pada tahap awal, penelitian ini diadakan observasi mengenai tingkat kreativitas anak usia dini pada saat mengikuti proses pembelajaran. Hasil pemantauan tingkat kreativitas anak pada observasi awal dapat dilihat pada Tabel 2.

Tabel 2. Data Tingkat Kreativitas Anak pada Observasi Awal

\begin{tabular}{|c|c|c|c|c|c|c|c|c|c|}
\hline \multirow{2}{*}{ No } & \multicolumn{4}{|c|}{ Indikator } & \multirow{2}{*}{ Jumlah } & \multirow{2}{*}{$\begin{array}{l}\text { Rata- } \\
\text { rata }\end{array}$} & \multirow{2}{*}{$\begin{array}{l}\text { Persentase } \\
\text { Penguasaan }\end{array}$} & \multirow{2}{*}{ Kategori } & \multirow{2}{*}{ Ketuntasan } \\
\hline & 1 & 2 & 3 & 4 & & & & & \\
\hline 1 & 4 & 2 & 3 & 2 & 11 & 2,75 & $69 \%$ & Sedang & Tuntas \\
\hline 2 & 2 & 1 & 1 & 3 & 7 & 1,75 & $44 \%$ & Sangat rendah & Belum Tuntas \\
\hline 3 & 2 & 2 & 2 & 1 & 7 & 1,75 & $44 \%$ & Sangat rendah & Belum Tuntas \\
\hline 4 & 2 & 1 & 1 & 1 & 5 & 1,25 & $31 \%$ & Sangat rendah & Belum Tuntas \\
\hline 5 & 2 & 1 & 2 & 3 & 8 & 2 & $50 \%$ & Sangat rendah & Belum Tuntas \\
\hline 6 & 4 & 3 & 2 & 2 & 11 & 2,75 & $69 \%$ & Sedang & Tuntas \\
\hline 7 & 2 & 2 & 1 & 3 & 8 & 2 & $50 \%$ & Sangat rendah & Belum Tuntas \\
\hline 8 & 2 & 1 & 2 & 1 & 6 & 1,5 & $38 \%$ & Sangat rendah & Belum Tuntas \\
\hline 9 & 3 & 3 & 3 & 2 & 11 & 2,75 & $69 \%$ & Sedang & Tuntas \\
\hline 10 & 2 & 2 & 2 & 3 & 9 & 2,25 & $56 \%$ & Rendah & Belum Tuntas \\
\hline 11 & 2 & 1 & 1 & 1 & 5 & 1,25 & $31 \%$ & Sangat rendah & Belum Tuntas \\
\hline 12 & 2 & 1 & 2 & 1 & 6 & 1,5 & $38 \%$ & Sangat rendah & Belum Tuntas \\
\hline
\end{tabular}




\begin{tabular}{|c|c|c|c|c|c|c|c|c|c|}
\hline \multirow{2}{*}{ No } & \multicolumn{4}{|c|}{ Indikator } & \multirow{2}{*}{ Jumlah } & \multirow{2}{*}{$\begin{array}{l}\text { Rata- } \\
\text { rata }\end{array}$} & \multirow{2}{*}{$\begin{array}{l}\text { Persentase } \\
\text { Penguasaan }\end{array}$} & \multirow{2}{*}{ Kategori } & \multirow{2}{*}{ Ketuntasan } \\
\hline & 1 & 2 & 3 & 4 & & & & & \\
\hline 13 & 2 & 2 & 1 & 3 & 8 & 2 & $50 \%$ & Sangat rendah & Belum Tuntas \\
\hline 14 & 2 & 1 & 1 & 1 & 5 & 1,25 & $31 \%$ & Sangat rendah & Belum Tuntas \\
\hline 15 & 4 & 3 & 3 & 2 & 12 & 3 & $75 \%$ & Sedang & Tuntas \\
\hline 16 & 2 & 2 & 1 & 3 & 8 & 2 & $50 \%$ & Sangat rendah & Belum Tuntas \\
\hline 17 & 2 & 3 & 3 & 3 & 11 & 2,75 & $69 \%$ & Sedang & Tuntas \\
\hline 18 & 2 & 2 & 2 & 2 & 8 & 2 & $50 \%$ & Sangat rendah & Belum Tuntas \\
\hline 19 & 2 & 2 & 2 & 1 & 7 & 1,75 & $44 \%$ & Sangat rendah & Belum Tuntas \\
\hline 20 & 2 & 2 & 3 & 2 & 9 & 2,25 & $56 \%$ & Rendah & Belum Tuntas \\
\hline 21 & 3 & 2 & 2 & 1 & 8 & 2 & $50 \%$ & Sangat rendah & Belum Tuntas \\
\hline 22 & 2 & 2 & 2 & 1 & 7 & 1,75 & $44 \%$ & Sangat rendah & Belum Tuntas \\
\hline
\end{tabular}

Keterangan indikator yang dimaskud adalah Indikator 1 yaitu fluency (kelancaran), Indikator 2 yaitu flexibility (keluwesan), Indikator 3 yaitu originality (keaslian), dan Indikator 4 yaitu elaboration (berpikir terperinci).

Bedasarkan Tabel 2 dapat diketahui tingkat krativitas anak masih rendah. Persentase ketuntasan hanya dicapai oleh 5 anak $(22,72 \%)$, dengan katagori sedang.
Tujuh belas anak $(77,28 \%)$ masih berada dibawah katagori sedang. Untuk itu perlu diberikan suatu tindak lanjut sebagai upaya perbaikan tingkat kreativitas anak. Peningkatan kreativitas anak dilakukan melalui penerapan pembelajaran inkuiri terbimbing berbasis permainan. Secara rinci nilai rata-rata kreativitas anak dalam mengkuti kegiatan pembelajaran pada siklus I dituangkan dalam Tabel 3.

Tabel 3 Data Tingkat Kreativitas Anak pada Siklus I

\begin{tabular}{|c|c|c|c|c|c|c|}
\hline No & \multicolumn{2}{|c|}{$\begin{array}{c}\text { Mean } \\
\text { Pertemuan ke- }\end{array}$} & $\begin{array}{l}\text { Rata- } \\
\text { rata }\end{array}$ & $\begin{array}{c}\text { Persentase } \\
\text { Penguasaa } \\
\mathbf{n}\end{array}$ & Kategori & Ketuntasan \\
\hline 1 & 3,25 & 3,5 & 3,375 & $84 \%$ & Tinggi & Tuntas \\
\hline 2 & 2 & 2,5 & 2,25 & $56 \%$ & Rendah & Belum Tuntas \\
\hline 3 & 2,75 & 2,75 & 2,75 & $69 \%$ & Sedang & Tuntas \\
\hline 4 & 1,25 & 1,25 & 1,25 & $31 \%$ & Sangat rendah & Belum Tuntas \\
\hline 5 & 2,25 & 3,25 & 2,75 & $69 \%$ & Sedang & Tuntas \\
\hline 6 & 3 & 3,75 & 3,375 & $84 \%$ & Tinggi & Tuntas \\
\hline 7 & 2 & 2,75 & 2,375 & $59 \%$ & Rendah & Belum Tuntas \\
\hline 8 & 1,75 & 1,5 & 1,625 & $41 \%$ & Sangat rendah & Belum Tuntas \\
\hline 9 & 2,75 & 2,75 & 2,75 & $69 \%$ & Sedang & Tuntas \\
\hline 10 & 2,5 & 3 & 2,75 & $69 \%$ & Sedang & Tuntas \\
\hline 11 & 2 & 2,75 & 2,375 & $59 \%$ & Rendah & Belum Tuntas \\
\hline 12 & 1,5 & 2 & 1,75 & $44 \%$ & Sangat rendah & Belum Tuntas \\
\hline 13 & 2 & 2,5 & 2,25 & $56 \%$ & Rendah & Belum Tuntas \\
\hline 14 & 1,5 & 2 & 1,75 & $44 \%$ & Sangat rendah & Belum Tuntas \\
\hline 15 & 3 & 3 & 3 & $75 \%$ & Sedang & Tuntas \\
\hline 16 & 2 & 2 & 2 & $50 \%$ & Sangat rendah & Belum Tuntas \\
\hline 17 & 2,75 & 2,75 & 2,75 & $69 \%$ & Sedang & Tuntas \\
\hline 18 & 2,5 & 3,25 & 2,875 & $72 \%$ & Sedang & Tuntas \\
\hline
\end{tabular}




\begin{tabular}{ccccclll}
\hline No & $\begin{array}{c}\text { Mean } \\
\text { Pertemuan ke- } \\
\mathbf{1}\end{array}$ & $\mathbf{2}$ & $\begin{array}{c}\text { Rata- } \\
\text { rata }\end{array}$ & $\begin{array}{c}\text { Persentase } \\
\text { Penguasaa }\end{array}$ & Kategori & Ketuntasan \\
\hline 19 & 2 & 2 & 2 & $50 \%$ & Sangat rendah & Belum Tuntas \\
20 & 2,75 & 2,75 & 2,75 & $69 \%$ & Sedang & Tuntas \\
21 & 3 & 3 & 3 & $75 \%$ & Sedang & Tuntas \\
22 & 2,5 & 2,75 & 2,625 & $66 \%$ & Sedang & Tuntas \\
\hline
\end{tabular}

Pada Tabel 3 tingkat kreativitas anak pada siklus I di atas terlihat bahwa terjadi peningkatan kreativitas anak. Hal ini ditunjukan dari semakin meningkatnya jumlah ketuntasan kreativitas anak yakni sebanyak 12 orang (54,54\%).

Berdasarkan hasil pemantauan kreativitas anak pada siklus I, masih ditemukan adanya anak yang kesulitan untuk menuangkan kreativitasnya.
Untuk itu pada siklus kedua kembali disusun persiapan pembelajaran dengan model inkuiri terbimbing berbasis permainan untuk meningkatkan kreativitas anak. Peningkatan kreativitas anak dilakukan melalui penerapan pembelajaran inkuiri terbimbing berbasis permainan. Secara rinci nilai ratarata kreativitas anak dalam mengkuti kegiatan pembelajaran pada siklus II dapat diperhatikan pada Tabel 4.

Tabel 4 Data Tingkat Kreativitas Anak pada Siklus II

\begin{tabular}{|c|c|c|c|c|c|c|}
\hline \multirow[b]{2}{*}{ No } & \multicolumn{2}{|c|}{ Mean Pertemuan } & \multirow{2}{*}{$\begin{array}{l}\text { Rata- } \\
\text { rata }\end{array}$} & \multirow{2}{*}{$\begin{array}{l}\text { Persentase } \\
\text { Penguasaan }\end{array}$} & \multirow{2}{*}{ Kategori } & \multirow{2}{*}{ Ketuntasan } \\
\hline & 1 & 2 & & & & \\
\hline 1 & 3,75 & 4 & 3,875 & $97 \%$ & Sangat Tinggi & Tuntas \\
\hline 2 & 3,25 & 3,75 & 3,5 & $88 \%$ & Tinggi & Tuntas \\
\hline 3 & 3,25 & 3,5 & 3,375 & $84 \%$ & Tinggi & Tuntas \\
\hline 4 & 2,25 & 2,5 & 2,375 & $59 \%$ & Rendah & Belum Tuntas \\
\hline 5 & 3,50 & 3,5 & 3,5 & $88 \%$ & Tinggi & Tuntas \\
\hline 6 & 3,75 & 3,75 & 3,75 & $94 \%$ & Sangat Tinggi & Tuntas \\
\hline 7 & 3,25 & 3,25 & 3,25 & $81 \%$ & Tinggi & Tuntas \\
\hline 8 & 2,25 & 2,5 & 2,375 & $59 \%$ & Rendah & Tuntas \\
\hline 9 & 2,75 & 3 & 2,875 & $72 \%$ & Sedang & Tuntas \\
\hline 10 & 3 & 3,25 & 3,125 & $78 \%$ & Sedang & Tuntas \\
\hline 11 & 2,75 & 3 & 2,875 & $72 \%$ & Rendah & Tuntas \\
\hline 12 & 3,25 & 3,75 & 3,5 & $88 \%$ & Tinggi & Tuntas \\
\hline 13 & 2,25 & 2,75 & 2,5 & $63 \%$ & Rendah & Belum Tuntas \\
\hline 14 & 2,50 & 3 & 2,75 & $69 \%$ & Sedang & Tuntas \\
\hline 15 & 3 & 3 & 3 & $75 \%$ & Sedang & Tuntas \\
\hline 16 & 2,75 & 3,25 & 3 & $75 \%$ & Sedang & Tuntas \\
\hline 17 & 2,75 & 3,5 & 3,125 & $78 \%$ & Sedang & Tuntas \\
\hline 18 & 3,25 & 3,25 & 3,25 & $81 \%$ & Tinggi & Tuntas \\
\hline 19 & 2,50 & 2,5 & 2,5 & $63 \%$ & Rendah & Belum Tuntas \\
\hline 20 & 3 & 3 & 3 & $75 \%$ & Sedang & Tuntas \\
\hline 21 & 3,75 & 3,75 & 3,75 & $94 \%$ & Tinggi & Tuntas \\
\hline 22 & 2,75 & 3,5 & 3,125 & $78 \%$ & Sedang & Tuntas \\
\hline
\end{tabular}


Pada Tabel 3, diungkapkan bahwa tingkat kreativitas anak pada siklus II kembali mengalami peningkatan. Hal ini ditunjukan dari semakin meningkatnya jumlah ketuntasan kreativitas anak yakni sebanyak 19 orang (86,36\%). Pada akhir siklus II ini, hanya menyisakan 3 orang anak yang masih belum bisa mengekspresikan kreativitasnya dan masih dalam kategori rendah. Namun diyakini apabila terus mendapatkan stimulus yang sesuai maka tingkat kreativitasnya akan semakin berkembang

Hasil pemantauan seperti yang dipaparkan disebelumnya menunjukkan bahwa secara umum tingkat kreativitas anak TK Pradnyandari III mengalami peningkatan. Ini ditunjukan dari perubahan tingkat kreativitas anak pada saat observasi awal dengan saat pelaksanaan siklus I dan siklus II. Pada Gambar 1, ditunjukan diagram perbandingan Persentase penguasaan kreativitas pada observasi awal, siklus 1 dan siklus II.

\section{Gambar 1. Diagram Perbandingan Persentase penguasaan kreativitas pada observasi awal, siklus I, dan siklus II}

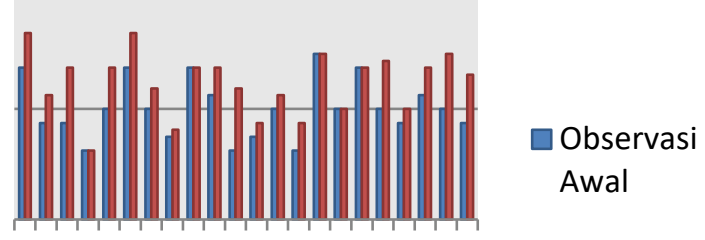

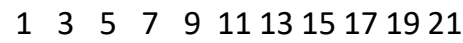

Pada Gambar 1 terlihat adanya peningkatan kreativitas anak usia dini. Pada saat observasi awal, hanya 5 anak (22,72 \%) yang mencapai ketuntasan. Setelah mengikuti pembelajaran dengan metode inkuiri terbimbing berbasis permainan pada siklus I terjadi peningkatan ketuntasan sebanyak 12 anak (54,54\%), dan pada siklus II meningkat menjadi 19 anak (86,36\%).

Pentingnya pengembangan kreativitas dilakukan sejak dini. Dikatakan demikian, karena setiap anak dilahirkan dengan adanya potensi kreatif di dalam diri mereka. Rahcmawati (2012) menyebutkan persoalan yang terjadi pada perkembangan selanjutnya menyebabkan daya kreatif anak semakin berkurang. Peraturan-peraturan, pola kebiasaan, pola penghargaan, dan pola asuh orang dewasa di sekitar anak dapat menghambat daya kreativitas anak tersebut. Untuk itu diperlukan metode yang teat dalam mengembangkan kreativitas anak usia dini.

Secara Teoritis, Metode Inkuiri terbimbing (Guided Inquiry) merupakan bagian dari kegiatan pembelajaran dengan pendekatan kontekstual. Dalam Sagala (2010) disebutkan bahwa Pengetahuan dan keterampilan yang diperoleh siswa diharapkan bukan hanya dari hasil mengingat fakta-fakta, melainkan juga dari menemukan sendiri. Pengetahuan dan keterampilan yang diperoleh siswa diharapkan bukan hanya dari hasil mengingat fakta-fakta, melainkan juga dari menemukan sendiri (Sanjaya, 2010).

Mudlofir (2016) menyebutkan bahwa pembelajaran Inkuiri merupakan kegiatan pembelajaran yang melibatkan secara maksimal seluruh kemampuan peserta didik untuk mencari dan menyelidiki sesuatu (benda, manusia atau peristiwa) secara sistematis, kritis, logis, analitis sehingga mereka dapat merumuskan sendiri penemuannya dengan percaya diri. Disebutkan pula bahwa ciri dari pembelajaran ini yakni satu menekankan kepada aktivitas peserta didik secara maksimal untuk mencari dan menemukan; dua seluruh aktivitas yang dilakukan peserta didik diarahkan untuk mencari dan menemukan jawaban sendiri dari sesuatu yang dipertanyakan; dan tiga tujuan penggunaan strategi pembelajaran inkuiri adalah mengembangkan kemampuan berpikir secara sistematis, kritis, logis dan analitis.

Pengembangan kreativitas anak usia dini mengacu pada arahan program pengembangannya (Rahcmawati, 2012). Arahan program pengembangan kreativitas pada anak usia dini tersebut yakni satu kegiatan belajar bersifat menyenangkan; dua) pembelajaran dalam bentuk kegiatan bermain; tiga mengaktifkan siswa; empat memadukan berbagai aspek pembelajaran dan perkembangan; dan lima pembelajaran dalam bentuk kegiatan yang konkret. Proses penemuan (inkuiri) dilakukan dengan hal yang dekat dengan dunia anak yakni melalui proses bermain. Melalui proses ini, siswa 
mampu menemukan dan memahami berbagai konsep penting serta mampu mengembangkan kreativitas mereka. Hal ini didukung dengan temuan empiris pada penelitian ini, dimana ditemukan bahwa penerapan pembelajaran inkuiri terbimbing berbasis permainan mampu meningkatkan kreativitas anak.

\section{SIMPULAN DAN SARAN}

Berdasarkan pemaparan di atas maka dapat ditarik simpulan sebagai berikut : pertama proses pembelajaran anak usia dini masih banyak yang menggunakan metode konvensional (teacher centered), ini mengakibatkan rendahnya kreativitas anak usia dini (hanya mencapai ketuntasan $22,72 \%$ pada observasi awal) , kedua penerapan pembelajaran inkuiri terbimbing berbasis permainan dapat meningkatkan kreativitas anak usia dini. Ini ditunjukan dari meningkatnya ketuntasan kreativitas pada siklus 1 menjadi $54,54 \%$, dan siklus II menjadi $86,36 \%$.

Saran yang dapat disampaikan dalam penelitian ini yakni sebagai berikut ; pertama meningkatkan kreativitas sangat dibutuhkan pada masa mendatang, perlu dilakukan penanganan dan pengembangan sedini mungkin. Kedua dibutuhkan dukungan dari semua pihak (peneliti, guru, orang tua) untuk mensukseskan upaya pengembangan kreativitas pada anak usia dini.

\section{DAFTAR PUSTAKA}

Agung, AA Gede. 2014. Metode Penelitian Pendidikan. Malang : Aditya Media Publising.

Ambarsari, W., \& Santosa, S. (2013). Penerapan Pembelajaran Inkuiri Terbimbing Terhadap Keterampilan Proses Sains Dasar Pada Pelajaran Biologi Siswa Kelas VIII SMP Negeri 7 Surakarta. Jurnal Pendidikan Biologi, 5(1), 81-95.

Andriani, I., Munawaroh, M., \& Nursuprianah, I. (2015). Perbandingan Kepercayaan Diri Siswa Dalam Belajar Matematika Antara Yang Menggunakan Metode Jigsaw Dengan Metode Inkuiri Terbimbing Di Kelas Vii Smp Satu
Atap Negeri Talun Kabupaten Cirebon. Kata Kunci: Kepercayaan Diri, Metode Jigsaw Metode Inkuiri Terbimbing EduMa, 4(2), 32-45.

Astuti, Y., \& Setiawan, B. (2013). Pengembangan Lembar Kerja Siswa (Lks) Berbasis Pendeka- Tan Inkuiri Terbimbing Dalam Pembelajaran Kooperatif Pada Materi Kalor Y. Jurnal Pendidikan IPA Indonesia, 2(1), 88-92.

Christianti, Marta. 2007. Anak dan Bermain. Makalah disajikan dalam Jurnal Club Prodi PGTK UNY dan majalah Edutot Pgtk UNY.

E. Mulyasa. (2007).menjadikan guru profesional menciptakan pembelajaran kreatif dan menyenangkan . bandung. Remaja Rosdakarya.

Fithriyana, A. (2014). Bimbingan Kelompok Dengan Teknik Permainan Simulasi Untuk Meningkatkan Kemampuan Komunikasi Antar Pribadi SISWA. Jurnal Bimbingan Konseling, 3(2), 138-142. Retrieved from http://journal.unnes.ac.id/sju/index.p hp/jubk

Gulo. W. (2004). Strategi Belajar Mengajar. Jakarta: PT Gramedia Widiasarana.

Hidayatullah, F. M. (2011). "Menjadi Guru Sejat". Makalah disajikan pada Seminar Nasional Himpunan Mahasiswa Pendidikan Biologi (HIMABI) FKIP, Universitas Sebelas Maret, 19 Maret.

Jumarni, N., Jalmo, T., \& Yolida, B. (2013). Pengaruh Penerapan Model Pembelajaran Inkuiri Terbimbing Terhadap Keterampilan Proses Sains Siswa. Jurnal Bioterdidik, 2(1). Retrieved from http://jurnal.fkip.unila.ac.id/index.php /JBT/article/view/2721.

Madya, Suwarsih. 2011. Penelitian Tindakan: Action Research; Teori dan Praktek. Bandung : Alfabeta. 
Maghfiroh, K., Asim, \& Sumarjono. (2013). Penerapan Model Pembelajaran Inkuiri Terbimbing Disertai Penugasan Portofolio Untuk Meningkatkan Hasil Belajar Fisika Siswa Kelas X-Cambridge MA Bilingual Batu. Journal of Chemical Information and Modeling, 53(9), 1689-1699.

https://doi.org/10.1017/CBO9781107 415324.004

Mudlofir, Ali \& Rusydiyah, E.F. 2016. Desain Pembelajaran Inovatif dari Teori ke Praktek. Depok: PT Rajagrafindo Persada.

Rachmawati, Yeni \& Kurniati, Euis. 2012. Strategi Pengembangan Kreativitas Pada Anak Usia Taman KanakKanak. Jakarta: Kencana Prenada Media Group.

Sagala, Syaiful. 2010. Konsep Dan Makna Pembelajaran. Bandung: Alvabeta.

Sanjaya, Wina. 2010. Strategi Pembelajaran Berorientasi Standar Proses Pendidikan. Jakarta: Kencana.

Sudarman, I. N. (2012, February 16). Pengaruh Model Pembelajaran Inkuiri Terbimbing Terhadap Pemahaman Konsep Dan Kinerja IImiah Siswa Smp. Jurnal Pendidikan
IPA. Retrieved from http://pasca.undiksha.ac.id/ejournal/index.php/jurnal_ipa/article/vi ew/411

Wahyudin, -, Sutikno, -, \& Isa, A. (2010). Keefektifan Pembelajaran

Berbantuan Multimedia

Menggunakan Metode Inkuiri

Terbimbing Untuk Meningkatkan Minat Dan Pemahaman Siswa. Jurnal Pendidikan Fisika Indonesia (Indonesian Journal of Physics Education), 6(1), 58-62. Retrieved from

http://journal.unnes.ac.id/nju/index.p $\mathrm{hp} / \mathrm{JPFl} /$ article/view/1105

Wartono. 1999. Metode Pembelajaran. Jakarta : Depdikbud.

Wijayanti, P. I., Mosik, -, \& Hindarto, N. (2010). Eksplorasi Kesulitan Belajar Siswa Pada Pokok Bahasan Cahaya Dan Upaya Peningkatan Hasil Belajar Melalui Pembelajaran Inkuiri Terbimbing. Jurnal Pendidikan Fisika Indonesia (Indonesian Journal of Physics Education), 6(1), 1-5. https://doi.org/10.15294/jpfi.v6i1.109 3. 